Instructions for authors, subscriptions and further details:

\title{
http://rimcis.hipatiapress.com
}

\section{'Sana All' Inclusive Education amid COVID-19: Challenges, Strategies, and Prospects of Special Education Teachers}

Cathy Mae D. Toquero ${ }^{1}$

1) Mindanao State Univesity-General Santos City, Philippines

Date of publication: Online First 26 January 2021; Issue published 30 March 2021

Edition period: March 2021 - July 2021

To cite this article: Toquero, C.M.D. (2021). 'Sana All' Inclusive Education amid COVID-19: Challenges, Strategies, and Prospects of Special Education Teachers. International and Multidisciplinary Journal of Social Sciences, 10(1), 30-51. doi: 10.17583/rimcis.2021.6316 To link this article: http://doi.org/10.17583/rimcis.2021.6316

\section{PLEASE SCROLL DOWN FOR ARTICLE}

The terms and conditions of use are related to the Open Journal System and to Creative Commons Attribution License(CC-BY). 


\section{'Sana All' Inclusive Education amid COVID-19: Challenges, Strategies, and Prospects of Special Education Teachers}

Cathy Mae D. Toquero

Mindanao State University-General

Santos City

\section{Abstract}

People with Special Educational Needs and Disabilities (SEND) are confronted with diverse challenges as COVID-19 caused tremendous disruption in face-to-face educational settings. Apart from this situation, teachers are also facing difficulties in making their lessons adaptive and responsive to the educational learning needs of people with SEND. This article explores the challenges, strategies, and prospects of teachers for inclusive education during the pandemic. Using a qualitative approach, the researcher gathered data through Messenger chatbot and emails from five special education teachers in the Philippines. Findings revealed that the teachers' experience educational apprehensions, intermittent virtual socialization, and psychological crisis. Nevertheless, the teachers assisted the parents in supervising their children with disabilities' through online communication, homeschooling, parental engagement, psychological safety, and empathetic language strategies. The special education teachers also look forward to inclusivity in school policies and government-driven emergency interventions for people with developmental disabilities.

Keywords: COVID-19, inclusive education, emergency remote teaching, special education teachers, developmental disabilities 


\section{Educación Inclusiva "Sana All" en medio de COVID-19: Desafíos, Estrategias y Perspectivas de los Maestros de Educación Especial}

Cathy Mae D. Toquero

Mindanao State University-General

Santos City

\section{Resumen}

Las personas con Necesidades Educativas Especiales y Discapacidades (SEND, por sus siglas en inglés) se enfrentan a diversos desafíos, ya que COVID-19 causó una tremenda interrupción en los entornos educativos cara a cara. Aparte de esta situación, los profesores también enfrentan dificultades para hacer que sus lecciones se adapten y respondan a las necesidades de aprendizaje educativo de las personas con SEND. Este artículo explora los desafíos, estrategias y perspectivas de los docentes para la educación inclusiva durante la pandemia. Utilizando un enfoque cualitativo, el investigador recopiló datos a través del chatbot Messenger y correos electrónicos de cinco maestros de educación especial en Filipinas. Los hallazgos revelaron que los maestros experimentan aprensiones educativas, socialización virtual intermitente y crisis psicológica. Sin embargo, los maestros ayudaron a los padres a supervisar a sus hijos con discapacidades mediante la comunicación en línea, la educación en el hogar, la participación de los padres, la seguridad psicológica y estrategias de lenguaje empático. Los maestros de educación especial también esperan la inclusión en las políticas escolares y las intervenciones de emergencia impulsadas por el gobierno para las personas con discapacidades del desarrollo.

Palabras clave: COVID-19, educación inclusiva, enseñanza remota de emergencia, maestros de educación especial, discapacidades del desarrollo 


\section{Toquero - 'Sana All' Inclusive Education amid COVID-19}

OVID-19 exacerbated marginalization, especially among the most vulnerable groups such as children with developmental disabilities. Amidst this panoply of adversity, "children may be at higher risk than in normal times for abuse or neglect, and with protective care agencies also working under extreme and strained conditions, recognition and intervention may be delayed' (Witt et al., 2020, p.2). Consequently, the pandemic heightens the stage for inequalities (Bešić, 2020; Brown, 2020; Dávalos et al., 2020; Hansen \& Yracheta, 2019; Poletti \& Raballo, 2020) until the postpandemic world, as these groups have not received the support that they seriously need during this emergency.

In the education sector, people with disabilities experienced the most aftermath as officials terminated the face-to-face educational activities (Daniel, 2020; Robbins et al., 2020). Likewise, among special education teachers, 'there is ambiguity and disagreement about what to teach, how to teach, the workload of teachers and students, the teaching environment, and the implications for education equity' (Zhang et al., 2020, p. 1). Teachers experience difficulties finding the virtual strategies that are attuned to an online curriculum in dealing with learners who have developmental disabilities. As a result, students with educational needs and disabilities suffer the most educational consequences, apart from the deprivation of their health essentials during the pandemic (Jalali et al., 2020; Safta-Zecheria, 2020).

In the Philippines, special education teachers stretch a hands-on approach in teaching their students with disabilities. However, this is even more challenging as they need to have an individualized approach through emergency e-learning or flexible learning while taking into account the different disabilities of their students. There were only 3, 050 elementary-level special education teachers in the country based on a draft report of the Department of Education in 2017-2018 (National Council on Disability Affairs, 2020). These teachers managed multiple disabilities in a conventional special education class before the pandemic. They also lack the specialized training they urgently need to supervise their learners with special educational needs and disabilities as they shifted to emergency remote instruction.

Apart from this, the Department of Education is eyeing on the realignment of the Special Education Fund (Medenilla, 2020) to help the government's precautionary measures against the virus. Though understandably, the government needs the finances in the fight against COVID-19 but at the 
expense of the Special Education Fund since funding the educational needs of the said learners is a priority in their rights to equal access to quality education. Nevertheless, these are desperate times but people and children with educational needs and disabilities should not be taken for granted to realize their rights, as have societies (Alper \& Goggin, 2017).

Inclusive education means creating access to all students to partake in the educational and social opportunities in society regardless of their conditions (Bešić, 2020; Toquero, 2020a). 'Sana all' is a newly existing and popular yet informal Filipino term that means 'hope everyone experiences that.' It is noteworthy to advocate for a re-schooled society (Brown, 2020) where all students, including people and children with special educational needs and developmental disabilities, can partake in building and developing a humane society in the post-pandemic era. Through Special Education (SPED), teachers accommodate those students with identified disabilities for the provision of specialized instructions to suffice their special needs for learning.

The purpose of this study is to shed light on how COVID-19 challenged the outworking of the educational systems worldwide, and so teachers experienced the tremendous stress and anxiety on their jobs (Bhat et al., 2020). The global pandemic also exposed a wide gap in the teacher training and preparation for emergency remote teaching (Trust $\&$ Whalen, 2020). Studies (Trust \& Whalen, 2020; Yang, 2020; Zhu \& Liu, 2020) revealed the general teachers' knowledge, experiences, and attitudes regarding their transitions to non-conventional education settings. However, no study focused on the special education teachers who manage the most vulnerable population during this emergency. It is highly significant for the teachers to provide inclusivity to alleviate the educational disparities among learners with special educational needs and developmental disabilities. Hence, the researcher explored the challenges that the special education teachers' experience, the strategies that they apply in dealing with the needs of their learners amid the pandemic, and the prospects that they have for inclusive education in the post-coronavirus period.

\section{Methodology}

This study applied the qualitative approach to describe the process in an expressive and persuasive language after the researcher collected the data and 


\section{Toquero - 'Sana All' Inclusive Education amid COVID-19}

analyzed the meaning of the participants' statements (Creswell, 2013). The researcher delved into the experiences and perceptions of five special education teachers. They were asked regarding the challenges they face to support the children with special educational needs and developmental disabilities during the pandemic, the strategies that they have applied in assisting the parents as home educators, and their prospects relative to the educational support that they need to help the children with developmental disabilities.

Due to the perplexing situation that the Department of Education is undergoing, teachers themselves are not free from worries in preparing their curricular activities. Among educators, Special Education (SPED) teachers face more challenges as they need to suit the learning materials to the needs of their students with different developmental disabilities. Hence, the researcher conducted a qualitative questionnaire and follow up interview with five special education teachers as the participants for this study. The researcher has known the three SPED teachers years ago but the two remaining teachers were referred to the researcher. Three among the five teachers were once recipients as finalists for outstanding special educators in the region-wide level in Mindanao, Philippines. All participants are licensed teachers who are teaching in the elementary level education for eight to ten years and as special education teachers for five to ten years.

The teachers came from two large populated schools-A and B. In school A, there were only three special education teachers who all joined as participants, while there were five special education teachers from school B, but only two agreed to join the study. The teachers catered to about twenty students with developmental disabilities, and they collaborated in their respective schools to mentor their students before the pandemic. They taught their students all together in a special education classroom. Their students included a mix of disabilities in conventional classrooms such as children with hearing impairment, visual impairment, autism, and intellectual disability in one class. Both schools are non-special education centers, but the schools have provisioned for special education classrooms with teachers who are trained to cater to students with special educational needs and developmental disabilities.

The study was conducted between the months of April to May 2020. In gathering the data, a semi-structured questionnaire was prepared for this 
study. The instrument was composed of five questions that asked the participant's experiences, perceptions, needs, challenges, and strategies to deal with the educational needs of people with special educational needs and disabilities.

The researcher informed the participants of the nature of the study. They were also given a consent form to ask for their voluntary participation in the study. They were informed of their rights as participants. Thereafter, the instrument was sent to the educators for them to read the interview questions. The educators asked to shift to a written interview instead so that they can freely express their thoughts to answer the questions and because they had to attend to home responsibilities to care for their kids without caregivers. They asked for enough time to contemplate on the interview questions. After two weeks, they returned their answers to the instrument through email. In a follow up online interview, the researcher utilized Facebook Messenger to ask them for further minute details about their profession and verification purposes of the responses of the participants.

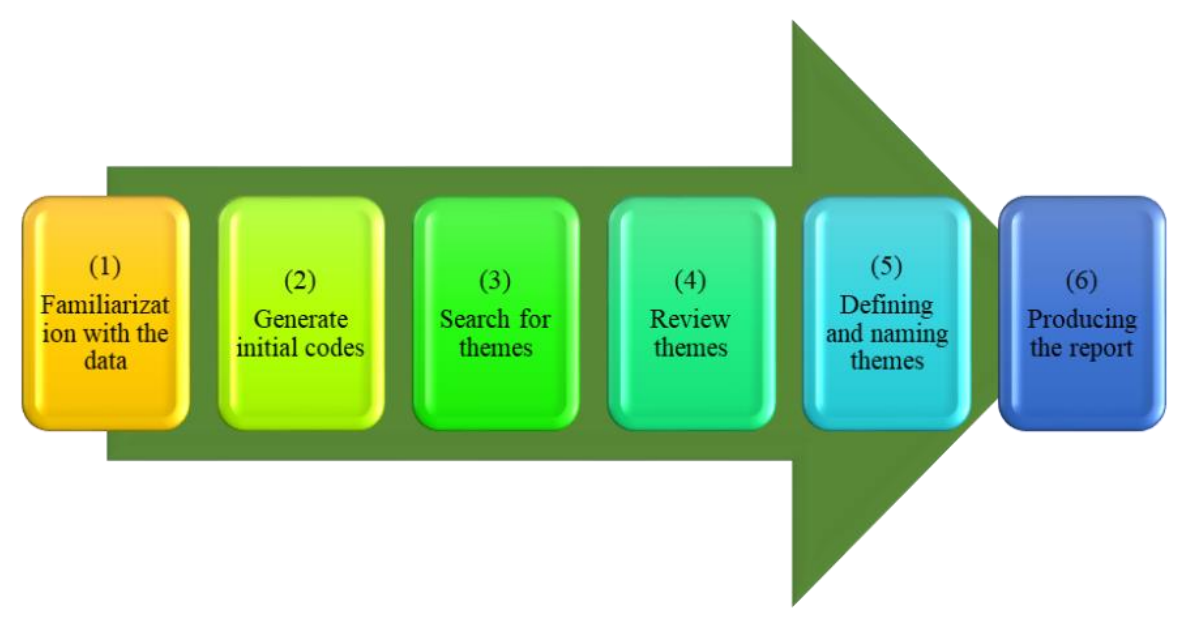

Figure 1. Six Phases Guidelines of Thematic Analysis

For data analysis, the researcher utilized the thematic analysis of Braun and Clarke (2006). The researcher applied thematic analysis in this qualitative 


\section{Toquero - 'Sana All' Inclusive Education amid COVID-19}

research by describing its procedures and processes. Thematic Analysis is a type of qualitative analysis that is used to analyze classifications and present themes (patterns) that relate to the data. The thematic analysis uses the data of diverse subjects and formulates interpretations (Boyatzis, 1998). The researcher created a diagram to illustrate Braun and Clarke's process (Figure 1) that shows the six phases guidelines of thematic analysis. It should be used concerning the research questions and the available data. In contrast, it should not be used as prescriptive, linear, and inflexible rules when analyzing data (Braun \& Clarke, 2006).

Thematic Analysis was considered the most appropriate for any study that seeks to discover using interpretations because it provides a systematic element to data analysis. It allows the researcher to associate analysis of a theme and confer accuracy and intricacy to enhance the research's study. Thematic Analysis allows understanding the potential of any issue more widely (Marks \& Yardley, 2004). By using thematic analysis, it is possible to analyze a large amount of data from multiple participants and synthesized those into a meaningful account (Boyatzis, 1998). Thus, this study utilized qualitative thematic analysis to investigate the experiences and perceptions of special education teachers.

\section{Results and Discussion}

COVID-19 exacerbated educational inequalities and inequities among the students, especially to the learners with special educational needs and developmental disabilities. Special Education (SPED) teachers, thereby, experienced experimentus crusis in dealing with the inadequacies of instruction to fulfil the needs of their SPED learners. Thus, this study is grounded on the experiences, strategies, and prospects of special education teachers. Figure 2 shows the themes that emerged from the SPED teachers' responses. 

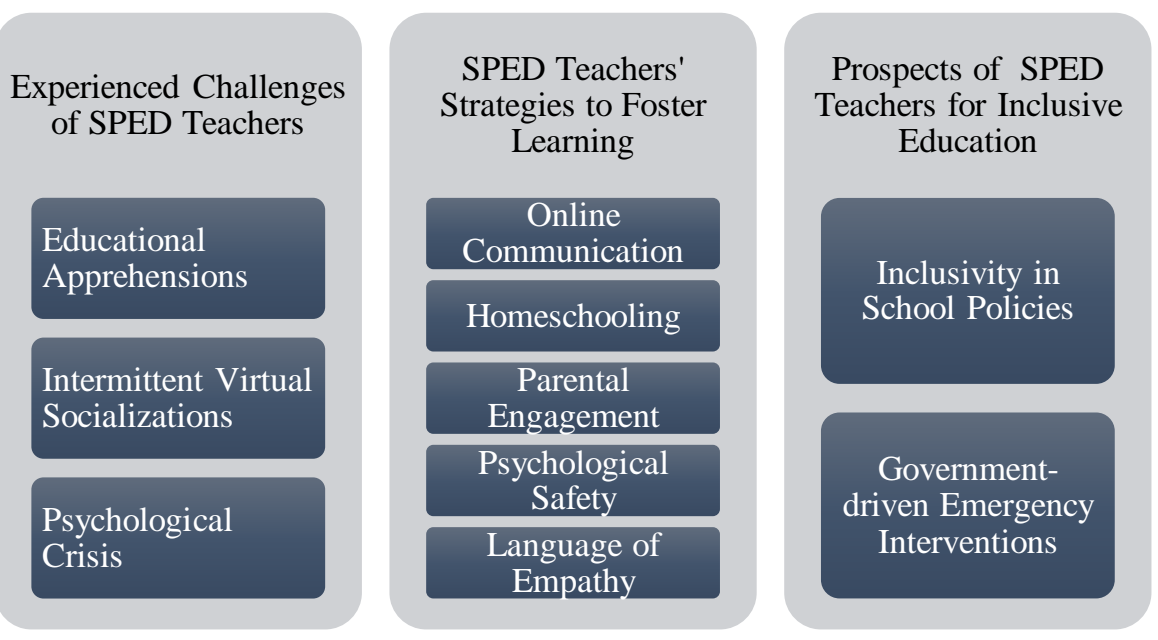

Figure 2. Emerging Themes from the Thematic Analysis of Special Education Teachers' Responses

\section{Challenges that Confront Special Education Teachers due to COVID-19}

When asked about the challenges that the educators have encountered in managing learners with developmental disabilities, the teachers answered that they have experienced educational, social, and psychological difficulties and challenges.

Educational Apprehensions. The special education teachers experienced educational disruptions related to module development, stakeholder communication, remote location, and monetary allocation. Due to the social distancing measures, the teachers in the Department of Education can no longer conduct face-to-face classes. The trend to proceed to the emergency remote teaching poses difficulties for the teachers since they are not trained in managing classes through the virtual environments, and it is even more difficult to deal with students who have special learning needs and developmental disabilities. 'In handling learners with special needs and 


\section{Toquero - 'Sana All' Inclusive Education amid COVID-19}

disabilities (LSENDS), there are lots of challenges we may encounter in delivering lessons especially in this S.Y. [school year] 2020-2021' (Teacher 3 ). This is confirmed in a study (Almaiah et al., 2020) that the shift to the emergency remote education becomes a primary challenge to several institutions. People with developmental disabilities need a curriculum and a learning space that is contextualized to their needs. However, Philippine teachers are not accustomed (Talidong, 2020; Toquero, 2020b) to the emergency e-learning spaces which present enormous challenges among the special education teachers.

The educators also clamored on the production of printable modules and worksheets such as the 'need for the learning materials like bondpapers, printer, ink, papers, and pencils' (Teacher 4). The teachers mentioned that they were not used to contextualizing the special education curriculum on the transition to emergency remote teaching, so this caused difficulty in module development. The teachers can undergo training based on their needs for module development and learning technologies (Daniel, 2020; Zhang et al., 2020) in the teaching process. Teacher 5 remarked: 'Making the module specialized for children with intellectual disability is really a great challenge since we do not have curriculum guides to follow that would suit our instruction when we teach online.' Likewise, the teachers handle students with different special educational learning needs and disabilities such as autism spectrum disorder, intellectual disability, and behavioral problems and they deemed it necessary to give these students an individualized approach for the learning process.

Aside from this, the educators emphasized the challenge of communicating with parents because not all parents have smartphones and social media accounts. The teachers communicate with parents to uplift them to build confidence that their children's educational opportunities are a priority in the educational system despite the crises. Giving reassurance to the parents is also a vital element as part of an institutional response (Daniel, 2020) to strengthen the relationship between the parents and the school community.

Likewise, three teachers said that transportation is also a challenge. The students are located in different areas while others are in a remote location, so it is a challenge to reach out to the learners during this pandemic since the clustering [separation through areas] limits the jurisdiction for their mobility 
to reach out to the parents of the learners with Special Educational Needs and Disabilities.

All the teachers stated that monetary allocation is also needed for homebased instruction and integrating technology can be expensive in the long term (Brown, 2020). They emphasized that financial limitation is part of the challenges during the outbreak. While technology is essential for students with special educational needs and disabilities to advance their literaciesbesides the teachers' clamor on finances, the use of technology is also out of reach to some students due to the same financial constraints. This result confirms the study of Alvarez (2020) that emergency remote education disruptions in the Philippines include poor internet access, financial limitations, and lack of learning technologies.

Intermittent Virtual Socializations. The isolation from other teachers and other people makes the situation even more difficult for educators since they were used to collaborating with their fellow educators and having personal communication with them. Teachers 1,2 , and 3 belong to the same school, and they said that before the pandemic, they shared concerns and issues to obtain advice from one another and demonstrate the practices to deal with a specific problem relative to the needs of their students. However, all teachers stressed that social media is an advantage for communicating with their fellow teachers considering the social distancing measures, although there are also hindrances when it comes to internet connectivity. They experienced intermittent connections at home, while sometimes, they lost internet connection when the signal is not stable. Teacher 1 said: 'All of a sudden, in a middle of the conversation in the Google Meet, I lost connection due to a very weak signal I have at home, so we have go for chat but it's hard to express my thoughts in chat if I want to suggest a strategy.'

Psychological Crisis. COVID-19 also posed a threat to the psychological well-being of the participants. Teacher 3 mentioned that she had no idea whether she can still survive the emergency, 'It's so threatening because the virus is just anywhere we don't know when this pandemic will end.' Teacher 2 also said: 'Everything is out of control even in our lives. We don't know if we can survive in this calamity.' 


\section{Toquero - 'Sana All' Inclusive Education amid COVID-19}

Despite the detrimental effects of COVID-19, special education teachers are still grateful for being alive and that their families are safe and healthy. Even though the situation is difficult to deal with as they experience anxieties due to the spread of the virus, the teachers said that COVID-19 creates more time for the family, so they are still hopeful. Hence, the special education teachers look forward to the future despite the constant threat of COVID-19 to their psychosocial well-being and their students. 'I'm worried regarding the conditions of my learners but I try to contact by texting the parents to ask how they are doing' (Teacher 5). Looking at a brighter side, Teacher 1 exclaimed: 'I'm happy because we have time with our family, bonding with our children taking care of the family full time.' Teacher 4: 'It's a time to contemplate, of loss of What if... But the most important thing is we have them [family] to pray together, and thanking God every day for the gift of Life. We are all still alive and healthy.'

The pandemic is a threat to everyone that presents a surging emotional response (Khosravi, 2020) to the current situation. People with developmental disabilities can experience mental health issues that affect their psychological health (Thabet, 2017). The special education teachers, likewise, are not immune to the anxiety and stress due to COVID-19 (Talidong \& Toquero, 2020).

\section{Strategies of Special Education Teachers to Foster Learning}

Online Communication. To support the learning needs of people with SEND, the educators consistently communicate with the parents of children with SEND. Social media has created opportunities to reinforce the learning of the students and for better human interaction since parents are also attuned to the use of social media. However, not all parents can access social media due to internet connectivity and lack of smartphones (Alvarez, 2020). Nonetheless, the teachers contact the parents through text messages or social media to give instructions or to know the familial, educational, and health status of their learners. 'Since we are all under community quarantine, we called the parents one by one, and through social media, we informed them about the modules and activity sheets we will be providing for home-based education' (Teacher 4). 
Based on the statements of the educators, the views elucidate the significance of social media as a platform for guiding the parents and communicating with fellow teachers during this pandemic. The teachers interact with parents through Facebook, which is the most used platform for social networking in the Philippines.

Homeschooling. Due to the social distancing measures, Teacher 5 also emphasized that 'parents can have all the time to guide and supervise the learners to do the modules and worksheets given by the teacher.' The parents can provide for the education of their children through home-based schooling (Brown, 2020; Cheng \& Donnelly, 2019; Farris, 2013) although this is a perennial debate relative to human rights, homeschooling effects, and academic outcomes (Cheng \& Donnelly, 2019; Farris, 2013). Nonetheless, homeschooling is reliant on parental supervision that is the only solution possible to mitigate educational interruption among children with disabilities amid the crises. Teacher 2 emphasized that the modules for the special learners will be answered of course with the supervision of their parents. We send also some educational videos for the children to watch and learn. We provide worksheets for them to answer. We see to it that the activities are fun yet educational and with learning.'

Parental Engagement. The teachers emphasized that the parents as homeschool supervisors can also socialize with their children while learning at home. The teachers regularly communicate with the parents to check how their children (learners) were doing at home. The teachers believed that family supervision strengthens learning, so parents should give children with SEND the learning space at home so that they can focus on the homeschool activities that their teachers gave to them. With appropriate supervision from the parents, students with disabilities can still learn during this pandemic. 'Though we are required to stay at home, the whole family has the chance to be socialized, have time for each other, knowing individual personality of each member of the family is a great opportunity to make the family closer' (Teacher 4). This result is supported by an article (Hart, Turnbull, Oppenheim \& Courtright, 2020) that the family care and support is pertinent during the pandemic. Times of hardship can create opportunities to solidify stronger 


\section{Toquero - 'Sana All' Inclusive Education amid COVID-19}

relationships (Cluver et al., 2020) between parents and children with special educational needs and disabilities.

On the contrary, a household that lacks parental support for their children's education can have a risk of lagging and widening pre-existing gaps (Thomas \& Rogers, 2020) that will result in more inequalities among children with disabilities.

Psychological Safety. The educators emphasized the moral support of the parents to their children can help the children cope with the adverse effects of COVID-19 on their psychological health. The teachers encourage the parents to give their children with SEND the psychological support they need during this emergency particularly in homeschooling. The parents understand and know their children better than the teachers, so they can assess the impact of COVID-19 on the psychological aspect of their children. 'Covid-19 pandemic is really alarming and threatening to every individual. We don't know what would happen in everyday of our lives, with the news around and around the world about the mortality rate of the pandemic. On the other hand, because of prayer and faith, everything will be settled for the better' (Teacher 3). Teacher 1 added: 'It's really scary, but the moral support given by each family members really gives courage to survive every day.'

The support and encouragement from the parents can create resilience among their children with disabilities to continue their educational endeavors despite the pandemic. The pandemic offers opportunities for growth, resilience, and extraordinary development even to children (Seery, 2011; Seery et al., 2010; Seery et al., 2013; Witt et al., 2020).

Language of Empathy. The educators also emphasized that parents can meet the emotional needs of their children with SEND. Since the parents faced the economic realities due to the pandemic (Witt et al., 2020), some children with SEND cannot go to the conventional school when classes resume. The teachers explained that parents should encourage the children to focus on their studies at home instead. The educators emphasized to understand the feelings of the children and then explain to them in a language that is understandable to them. 'Parents are more affected by the pandemic because the source of income has been paralyzed. Parents are more influential to let their children understand emotionally the situation on today's pandemic' (Teacher 2). 
Additionally, Teacher 3 said that parents should 'explain to them [children] that as of now they will be no longer go to [physical] school.'

Witt et al. (2020) advised that 'parents have the role of explaining the pandemic and its consequences to their children, and to manage and contain the fear and anxiety that accompanies everyone in the family during these uncertain times' (p. 2).

\section{Prospects of Special Education Teachers in Post-Pandemic}

The researcher asked the teachers about the mitigation strategies of the school to prevent the spread of the virus. They were also asked about their prospects on possible interventions to help the students with SEND. Teacher 5 said that 'the process of reopening of schools might be gradual, as authorities will want to reduce agglomeration or the possibility of a second wave of the pandemic.' Spaull (2020) pointed out that in the reopening of schools, the governments need to find balance on the costs and benefits of the unintended and indirect suffering and demises that result from the mitigation strategies.

Inclusivity in School Policies. The educator's above statement is a similar concern among institutions of learning. In the post-pandemic period, it is still vital to consider preventive measures to contain the virus and strategic plans for re-education (Poletti \& Raballo, 2020). School policies can help curb the virus, so there are precautions and advisories from the Department of Education from time to time. 'The policies of the school need to be inclusive so that learners with SEND can still learn even during the pandemic' (Teacher 1). Teacher 2 mentioned that: 'The Department of Education is on the process of planning on how to continue the education on the special learners even at home where the school follows and implements the memorandum coming from DepEd.'

In that case, the school needs to create policies and guidelines that are inclusive and specific to students with educational needs and developmental disabilities to better supplement emergency e-inclusion for them during the pandemic. Inclusivity in the school policies paves the way for all students to access and experience equal participation (UNESCO, 2005) in the virtual learning environments or the educational system as an entirety. Bešić (2020) argued that because of the changing conditions permeating in the world, 


\section{Toquero - 'Sana All' Inclusive Education amid COVID-19}

inclusive education needs to be redefined in a deeper understanding to include all the students in school outworking no matter their situations.

Government-driven Emergency Interventions. COVID-19 presents the opportunity for societal transformation (Dávalos et al., 2020). The education sector of the Philippine Government needs to be inclusive to uphold the rights of people with SEND. As a provision to the educational needs of the learners in e-inclusion through emergency remote teaching, a specialized virtual learning environment and a specialized remote curriculum should be created to meet their needs. The educators pointed out that they will follow what the government efforts are giving and doing to help the students with their learning. Teacher 5 pointed out that 'DepEd is considering different options to provide quality education in spite of the outbreak. It is very challenging, but I know our dependable leaders can think of the best intervention for these challenges.' Teacher 3 added: I believe the best intervention I can recommend is to pray and trust to the Lord that these leaders be given wisdom how to deal with this problem.'

The educators also gave the learning options or diverse modalities for the approaching school year that the government has prepared for the students. The alternative options are 1) online learning through a learning management system, 2) modular learning/off e-learning through the use of Alternative Delivery Modules, 3) blended delivery - in which assessment may be conducted in school or online, 4) face-to-face and modular learning in which students and teachers will just report on certain days, 5) traditional face-toface which is implemented only in schools with very low-risk level areas, and, 6) home-based learning in which teachers do a form of home visitations to their learners. The special education teachers are organizing the needs in the curriculum, and currently undergoing webinar-based training to mitigate the possible impacts of the pandemic to their students with special educational needs and disabilities. From time to time, the Department of Education provides the teachers with relevant training through Google Meet. Similarly, Zhang et al. (2020) also suggested that:

The government needs to further promote the construction of the educational information superhighway, consider equipping teachers and students with standardized home-based teaching/ learning equipment, conduct online teacher training, include the development of massive online education in the national 
strategic plan, and support academic research into online education, especially education to help students with online learning difficulties (Zhang et al., 2020, p. 1).

Although institutions with conventional classrooms will return to normality in the post-pandemic period, the special arrangements that the special education teachers with the aid of the government have given to their students with special educational needs and disabilities will leave a lasting trace (Daniel, 2020). Hence, the teachers need to provide the vital elements of the curriculum but, they should also be mindful and empathetic to the interests, needs, and situations of the students with disabilities in a time of uncertainty.

\section{Limitations}

The researcher interviewed only five teachers who can give useful insights into the plight of the special education teachers, so the results of the study cannot be generalized to other special education teachers. Due to the ongoing home quarantine, the researcher encountered difficulties in reaching out to the rest of the special education teachers. Hence, they were not included to share their insights for this study. Likewise, there are very few schools that specialize catering to special education students in the said locale, but these schools were not reached due to the clustering of areas that hindered the mobility of the researcher during the pandemic. This study is also limited to the perceptions and experiences of educators. Other aspects have not been considered in the study, such as the experiences of the parents or the learners themselves. Lastly, the study employed a written interview through a semistructured questionnaire that limits interaction for probing of the teachers' responses, so the researcher was also limited on the data analysis. An actual online interview could have added quality to the results.

\section{Future Directions}

Future research can include the parents and the learners themselves as part of the study to enrich the findings of this research. This study has academic implications such that a needs assessment survey should be created to identify the specific needs of the learners with SEND. Likewise, a specialized online or remote curriculum can be created to address the needs of the special 


\section{Toquero - 'Sana All' Inclusive Education amid COVID-19}

education teachers and learners. The special education teachers should also receive training on e-inclusion and module-making that are contextualized to the current and specific needs of the learners. Lastly, policymakers should also have a disability lens in crafting their policies and guidelines to have inclusivity in their formulation of educational policies.

\section{Conclusion}

Educators need to maximize the learning of people with special educational needs and disabilities despite the pandemic. There are educational, social, and psychological challenges due to the outbreak that posit difficulties in the pedagogical instruction of the teachers through emergency remote teaching, but there are also possible strategies so that people with SEND can learn. The strategies such as online communication, home-schooling, parental engagement, psychological safety, and language of empathy can support people with SEND to assist them in pursuing their educational endeavors amid the emergency. The schools need to be inclusive with their policies and guidelines so that people with SEND can also partake in the educational provisions of the government. The interventions of the government should integrate the educational needs of the children with SEND. The welfare of the people with SEND should not be dismissed as they are also part of the future generations who can make a better change for society. People with developmental disabilities are capable of changing the post-pandemic society so long as they are given the learning spaces and stakeholder support that they need right now to thrive amid this global crisis. They can achieve their maximum potentials akin to people with disabilities who changed the world. The notion surrounding 'sana all' [I hope the same for everybody] should not just remain as expressed hopes amid the new normal, but rather an accomplished reality of universal access to education so that people with disabilities can thwart inequalities in the post-pandemic period. 


\section{References}

Almaiah, M.A., Al-Khasawneh, A., \& Althunibat, A. (2020). Exploring the critical challenges and factors influencing the E-learning system usage during COVID-19 pandemic. Education and Information Technologies, 25, 5261-5280.

https://doi.org/10.1007/s10639-020-10219-y

Alper, M., \& Goggin, G. (2017). Digital technology and rights in the lives of children with disabilities. New Media and Society, 19(5), 726-740. http://doi.org/10.1177/1461444816686323

Alvarez, A. Jr. (2020). The phenomenon of learning at a distance through emergency remote teaching amidst the pandemic crisis. Asian Journal of Distance Education, 15(1), 144-153. https://doi.org/10.5281/zenodo.3881529

Bhat, R., Singh, V. K., Raghavendra Kamath, N. N., Mulimani, P., \& Kulkarni, N. (2020). COVID 2019 outbreak: The disappointment in Indian teachers. Asian Journal of Psychiatry, 50(102047). https://doi.org/10.1016/j.ajp.2020.102047

Bešić, E. (2020). Intersectionality: A pathway towards inclusive education? Prospects, 49, 111-122. https://doi.org/10.1007/s11125-020-09461-6

Braun, V., \& Clarke, V, (2006). Using thematic analysis in psychology. Qualitative Research in Psychology, 3(2), 77-101. https://doi.org/ 10.1191/1478088706qp063oa

Boyatziz, R. (1998). Transforming qualitative information: Thematic analysis and code development. Sage Publications, Inc.

Brown, G. (2020). Schooling beyond COVID-19: An Unevenly Distributed Future. Frontiers in Education, 5(82), 1-4. https://doi.org/10.3389/feduc.2020.00082

Cluver, L., Lachman, J., Sherr, L., Wessels, I., Krug, E. Rakotomalala, S., ... \& McDonald, K. (2020). Parenting in a Time of COVID-19. The Lancet, 395, e64. https://doi.org/10.1016/S01406736(20)30736-4

Creswell, J.W. (2013). Qualitative Inquiry \& Research Design. Choosing among Five Approaches ( $3^{\text {rd }}$ ed.) Thousand Oaks, CA. SAGE 
Daniel, S. J. (2020). Education and the COVID-19 pandemic. Prospects, 49, 91-96. https://doi.org/10.1007/s11125-020-09464-3

Dávalos, L., Austin, R., Balisi, M., Begay, R., Hofman, C., ... \& Yracheta, J. (2020). Pandemics' historical role in creating inequality. Science, 368(6497), 1322-1323.

https://doi.org/10.1126/science.abc8953

Cheng, A., \& Donnelly, M. (2019) New Frontiers in Research and Practice on Homeschooling, Peabody Journal of Education, 94(3), 259-262, https://doi.org/10.1080/0161956X.2019.1617576

Farris, M. (2013). Tolerance and Liberty: Answering the Academic Left's Challenge to Homeschooling Freedom. Peabody Journal of Education, 88(3), 393-406.

https://doi.org/10.1080/0161956X.2013.798520

Hansen, T., \& Yracheta, J. (2019, December 30). Indigenous migrant children at higher risk for flu-related deaths, yet denied basic flu shot. Cultural Survival. https://www.culturalsurvival.org

Hart, J., Turnbull, A., Oppenheim, I., \& Courtright, K. (2020). FamilyCentered during the COVID-19 Era. Journal of Pain and Symptom Management, 60(2).

https://doi.org/10.1016/j.jpainsymman.2020.04.017

Jalali, M., Shahabi, S., Lankarani, K.B., Kamali, M., \& Mojgani, P. (2020) COVID-19 and disabled people: perspectives from Iran.

Disability \& Society, 35(5), 844-847.

https://doi.org/10.1080/09687599.2020.1754165

Khosravi, M. (2020). Perceived Risk of COVID-19 Pandemic: The Role of Public Worry and Trust. Electronic Journal of General Medicine, 17(4), em203. https://doi.org/10.29333/ejgm/7856

Marks, D., \& Yardley, L. (2004). Research Methods for Clinical and Health Psychology. Sage Publications.

Medenilla, S. (2020, May 05). DepEd eyes realignment of Special Education Fund amid COVID-19 crisis (Weblog post).

https://businessminor.com.ph/2020/05/05/deped-eyes-realignmentof-special-education-fund-amid-covid-19-crisis/

National Council on Disability Affairs (2020, June 27). DEPED-Relevant numbers in relation to learners with disabilities. Department of 
Education. Republic of Phillipines.

https://www.ncda.gov.ph/disability-data/

Poletti, M., \& Raballo, A. (2020). Letter to the editor: Evidence on school closure and children's social contact: useful for coronavirus disease (COVID-19)? Eurosurveillance, 25(17), pii=2000758. https://doi.org/10.2807/1560-7917.ES.2020.25.17.2000758

Robbins, T., Hudson, S., Ray, P., Sankar, S., Patel, K., Randeva, H., \& Arvanitis, T. (2020). COVID-19: A new digital dawn? Digital Health, 6, 1-3. https://doi.org/10.1177/2055207620920083

Seery, M.D., Holman, E.A., \& Silver, R.C. (2010). Whatever does not kill us: cumulative lifetime adversity, vulnerability, and resilience. Journal of Personality and Social Psychology, 99(6), 1025-1041. https://doi.org/10.1037/a0021344

Seery, M.D. (2011). Resilience: a silver lining to experiencing adverse life events? Current Directions in Psychological Science, 20(6), 390-394. https://doi.org/10.1177\%2F0963721411424740

Seery, M.D., Leo, R.J., Lupien, S.P., Kondrak, C.L., \& Almonte, J.L. (2013). An upside to adversity? Moderate cumulative lifetime adversity is associated with resilient responses in the face of controlled stressors. Psychological Science, 24(7), 1181-1189. https://doi.org/10.1177/0956797612469210

Spaull, N. (2020). COVID-19 and schooling in South Africa: Who should go back to school first? Prospects. https://doi.org/10.1007/s11125020-09470-5

Talidong, K.J. (2020). Implementation of emergency remote teaching (ERT) among Philippine teachers in Xi'an, China. Asian Journal of Distance Education, 15(1), 196-201.

https://doi.org/10.5281/zenodo.3881825

Talidong, K.J., \& Toquero, C.M. (2020). Philippine Teachers' Practices to Deal with Anxiety amid COVID-19. Journal of Loss and Trauma, 25(6-7. Loss and Trauma in the COVID-19 Era), 573579. https://doi.org/10.1080/15325024.2020.1759225

Thabet, A.M. (2017). Coping and Mental Health of Children with Special Needs in the Gaza Strip. JOJ Nurse Health Care, 4(3), 555637. https://doi.org/10.19080/JOJNHC.2017.04.555637 
Thomas, M., \& Rogers, C. (2020). Education, the science of learning, and the COVID-19 crisis. Prospects, 49, 87-90. https://doi.org/10.1007/s11125-020-09468-z

Trust, T., \& Whalen, J. (2020). Should Teachers be trained in Emergency Remote Teaching? Lessons Learned from the COVID-19 Pandemic. Journal of Technology and Teacher Education, 28(2), 189-199. https://www.learntechlib.org/primary/p/215995

Toquero, C.M. D. (2020a). Inclusion of People with Disabilities amid COVID-19: Laws, Interventions, Recommendations Multidisciplinary Journal of Educational Research, 10(2), 158177. http://dx.doi.org/10.447/remie.2020.5877

Toquero, C. M. D. (2020b). Emergency remote teaching amid COVID19: The turning point. Asian Journal of Distance Education, 15(1), 185-188. https://doi.org/10.5281/zenodo.3881748

UNESCO (2005). Guidelines for inclusion: Ensuring access to education for all. Paris: UNESCO.

Witt, A., Ordóñez, A., Martin, A., Vitiello, B., \& Fegert, J. (2020). Child and adolescent mental health service provision and research during the Covid-19 pandemic: challenges, opportunities, and a call for submissions. Child and Adolescent Psychiatry and Mental Health, 14(19), 1-4. https://doi.org/10.1186/s13034-020-00324-8

Yang, X. (2020). Teachers' Perceptions of Large-Scale Online Teaching as an Epidemic Prevention and Control Strategy in China. ECNU Review of Education, 3(4), 1-6. https://doi.org/10.1177/2096531120922244

Safta-Zecheria, L. (2020). Challenges posed by COVID-19 to the health of people with disabilities living in residential care facilities in Romania. Disability \& Society, 35(5), 837-843. https://doi.org/10.1080/09687599.2020.1754766

Zhang, W., Wang, Y., Yang, L., \& Wang, C. (2020). Suspending Classes Without Stopping Learning: China's Education Emergency Management Policy in the COVID-19 Outbreak. Journal of Risk Financial Management, 13(55), 1-6. https://doi.org/10.3390/jrfm13030055

Zhu, X., \& Liu, J. (2020). Education in and After Covid-19: Immediate Responses and Long-Term Visions. Postdigital Science and 
International and Multidisciplinary Journal of Social Sciences, 10(1) 51

Education, 2(10), 695-699. https://doi.org/10.1007/s42438-02000126-3

Cathy Mae D. Toquero is Assistant Professor IV of the College Education, Mindanao State University-General Santos City, Philippines

Email: cathymaetoquero@gmail.com 